\title{
Vandetanib and ADAM inhibitors synergistically attenuate the pathological migration of EBV-infected retinal pigment epithelial cells by regulating the VEGF-mediated MAPK pathway
}

\author{
DAEJIN KIM ${ }^{1,3^{*}}$, HYUN-SUK KO ${ }^{1 *}$, GA BIN PARK ${ }^{1,3}$, \\ DAE YOUNG HUR ${ }^{1,3}$, YEONG SEOK KIM ${ }^{1}$ and JAE WOOK YANG ${ }^{2,3}$ \\ Departments of ${ }^{1}$ Anatomy and ${ }^{2}$ Ophthalmology; ${ }^{3}$ Ocular Neovascular Disease Research Center, \\ Inje University College of Medicine, Inje University Busan Paik Hospital, Busan 614-735, Republic of Korea
}

Received October 20, 2015; Accepted November 25, 2016

DOI: $10.3892 /$ etm.2017.4110

\begin{abstract}
The extracellular signals induced by vascular endothelial growth factor (VEGF) are implicated in choroidal neovascularization (CNV) and thus, are associated with vision-limiting complications in the human retina. Vandetanib is an oral anticancer drug that selectively inhibits the activities of VEGF receptor and epidermal growth factor receptor tyrosine kinase; however, the effects of vandetanib on VEGF in retinal pigment epithelial (RPE) cells have not yet been studied. In the present study, a combined treatment of vandetanib and a disintegrin and metalloproteinase (ADAM) protein inhibitors were used to assess the regulation of Epstein-Barr virus (EBV)-infected ARPE19 cells (ARPE19/EBV) migration as a model of CNV. Vandetanib suppressed the expression of the mesenchymal markers ADAM10 and ADAM17 in ARPE19/EBV cells, and also upregulated epithelial cell markers of the RPE cells, E-cadherin and N-cadherin. The migratory activity of ARPE19/EBV induced by VEGF was efficiently blocked by vandetanib. Furthermore, co-treatment with vandetanib and an ADAM10 inhibitor (GI254023X) or ADAM17 inhibitor (Marimastat) synergistically prevented migration and the expression of vimentin, Snail and $\alpha$-smooth muscle actin by regulating extracellular signal-regulated kinase and p38 mitogen-activated protein kinase. These results suggest that a combination treatment of vandetanib and ADAM inhibitors
\end{abstract}

Correspondence to: Professor Jae Wook Yang, Department of Ophthalmology, Inje University College of Medicine, Inje University Busan Paik Hospital, Bokjiro-75, Busan 614-735, Republic of Korea E-mail: eyeyang@inje.ac.kr

*Contributed equally

Key words: vandetanib, disintegrin and metalloprotease protein, retina pigment epithelial cells, vascular endothelial growth factor, epithelial-mesenchymal transition may be developed as a novel therapeutic regimen to control retina neovascular disease.

\section{Introduction}

Vascular endothelial growth factor (VEGF) is essential for tumor neovascularization, which leads to the formation of blood vessels within a tumor and facilitates cancer cell survival, local tumor growth and the development of distant metastases (1). VEGF is also a primary mediator of angiogenesis and vascular leakage in exudative age-related macular degeneration (AMD) $(2,3)$. Additionally, VEGF is an autocrine survival factor for a number of cell types and a critical factor for the retina during development and maturity (4). VEGF binds to two distinct receptors, VEGF receptor 1 (VEGFR1) and VEGF receptor 2 (VEGFR2); however, VEGFR2 is considered to be the dominant signaling receptor for endothelial cell permeability, differentiation and proliferation $(5,6)$.

Wet AMD is characterized by the presence of choroidal neovascularization (CNV) in which newly formed blood vessels from choriocapillaris penetrate through Bruch's membrane (BM) and retinal pigment epithelial (RPE) cells $(7,8)$. Wet AMD accounts for $<10 \%$ of AMD, but serious complications may arise if it is left untreated, leading to the development of retinal detachment and blindness $(9,10)$. Elevated levels of VEGF were identified in vitreous samples from patients with retinal neovascular diseases, indicating that VEGF serves a role in retinal disorders (11). RPE cells, which are located between the choroid and retina, serve a critical role in the pathogenesis of AMD (12). RPE cells also secrete various cytokines, chemokines and growth factors, including interleukin (IL)-6, IL-11, chemokine (C-X-C motif) ligand 9, platelet-derived growth factor, transforming grow th factor- $\beta$ (TGF- $\beta$ ) and VEGF (13). Hypoxia results in the increased expression of VEGF and IL-6, which are associated with increased angiogenesis, cell migration and invasion (14). It has been demonstrated that TGF- $\beta$ and VEGF markedly upregulate Snail mRNA, which is associated with the epithelial-mesenchymal transition (EMT), while no cytokines are known to affect the expression of transcriptional 
factors associated with EMT in adult retinal pigment epithelium-19 (ARPE19) cells (15). Based on these results, current treatments for AMD primarily focus on anti-VEGF therapies due to the association of CNV and EMT with VEGF $(16,17)$.

Vandetanib is a small molecule kinase inhibitor that inhibits the tyrosine kinase activity of VEGFR2, as well as angiogenesis (18). Vandetanib regulates tumor growth and vasculature in lung cancer by inhibiting epidermal growth factor receptor (EGFR) and VEGFR2 when administered as a single agent or used in combination with chemotherapy $(19,20)$. Vandetanib inhibits not only growth factor-induced phosphorylation of EGFR, mitogen-activated protein kinase (MAPK), VEGFR2 and protein kinase $\mathrm{B}(\mathrm{Akt})$, but also colony formation and invasion of breast cancer cells (21). Constitutive VEGF expression and secretion decreases following p38 inhibition, while no clear effect is observed following the inhibition of extracellular signal-regulated kinase (ERK) or c-Jun $\mathrm{N}$-terminal kinase (JNK) (22). However, there is no specific information regarding the use of vandetanib in preclinical or clinical ocular pathological conditions.

A disintegrin and metalloproteinase (ADAM) 10 and ADAM17 proteins are widely expressed in the differential layers of the retina throughout the embryonic period and are essential for a number of biological processes. These include cell fate determination, angiogenesis, cell migration and wound healing (23-25). VEGF enhances VEGFR2 shedding via ADAM17, which is activated by the ERK and MAPK pathways (26). EBV-infected human corneal epithelial cells (HCECs) have previously been generated, which cause EMT by enhancing the secretion of IL-6, IL-8, VEGF, TGF- $\beta 1$, tumor necrosis factor (TNF)- $\alpha$ and monocyte chemoattractant protein-1, as well as phosphoinositide 3-kinase (PI3K)/Akt and ERK signaling activation (27). EMT is a characteristic phenotypical change observed in patients with proliferative vitreoretinopathy (PVR) (28). RPE cells are crucial for the formation of fibrous tissue on the detached retina and EMT in PVR (29); however, to the best of our knowledge, there is currently no specific model for studying the effect of vandetanib on ADAM expression and cellular regulatory mechanism in RPE cells. In the present study, EBV-infected RPE cells (ARPE19/EBV) were produced as an in vitro model of EMT-related retinopathy, which expressed the mesenchymal phenotypes. The effect of vandetanib on ADAM expression and EMT using ARPE19/ EBV that secreted VEGF and the signaling pathway that is involved in EBV-infected ARPE cells as a model of CNV or PVR, was investigated to assess their application in a clinical setting.

\section{Materials and methods}

Cell culture and reagents. Cells from the human retinal pigment epithelial cell line ARPE19 were purchased from the American Type Culture Collection (ATCC; Manassas, VA, USA). The cells were maintained in Dulbecco's modified Eagle's medium/F12 (DMEM/F12; HyClone; Logan, UT, USA) supplemented with $10 \%$ fetal bovine serum (FBS; HyClone; GE Healthcare Life Sciences) and penicillin (100 U/ml)-streptomycin (100 $\mu \mathrm{g} / \mathrm{ml}$; Gibco; Thermo Fisher Scientific, Inc., Waltham, MA, USA) under a humidified atmosphere with $5 \% \mathrm{CO}_{2}$. For the generation of EBV-infected ARPE19 cells, cell-free EBV virions were prepared from the B95-8 cell line (EBV type I; ATCC), as previously described (27). Briefly, the B95-8 cells were grown in RPMI1640 medium (HyClone; GE Healthcare Life Sciences) supplemented with streptomycin, glutamine, and 10\% FBS for $48 \mathrm{~h}$ at $37^{\circ} \mathrm{C}$ in an atmosphere containing $5 \% \mathrm{CO}_{2}$. The infectious culture supernatant was harvested, centrifuged (200 x $g$ for $10 \mathrm{~min}$ at $25^{\circ} \mathrm{C}$ ), and filtered using a $0.2-\mu \mathrm{m}$-pore filter (Corning Inc., Corning, NY, USA) to remove cell debris. Following the attachment of the ARPE19 cells ( $2 \times 10^{5}$ cells/T25 flask/4 ml media), an equal volume of EBV supernatant $(4 \mathrm{ml}, 73 \pm 11 \mathrm{CFU} / \mathrm{ml})$ was added. EBV infection was confirmed using reverse transcription-quantitative polymerase chain reaction (RT-qPCR) and immunoblotting to detect viral transcripts and proteins, at four weeks following infection with EBV. Human recombinant VEGF was purchased from Human Biosciences, Inc. (Gaithersburg, MD, USA). Vandetanib was purchased from SelleckChemicals (Houston, TX, USA). GI254023X, Marimastat and ONO4817 were purchased from Tocris Bioscience (Bristol, UK). The Ethics committee and Institutional Review Board of the College of Medicine, Inje University (Busan, Korea) approved all protocols and procedures used in the present study.

Cell viability assay. The effect of vandetanib on the cell viability of ARPE19 and ARPE19/EBV cells was evaluated using an MTT assay (Sigma Aldrich; Merck KGaA, Darmstadt, Germany). The cells were seeded at a density of $1-2 \times 10^{4}$ cells/well in a 96-well plate and treated with various concentrations $(10,50,100$, and $500 \mathrm{nM})$ of vandetanib. Following 48 and $72 \mathrm{~h}$ incubation at $37^{\circ} \mathrm{C}, 30 \mu \mathrm{l}$ MTT solution $(1 \mathrm{mg} / \mathrm{ml})$ was added to each well. The formazan dye, part of the MTT assay, was dissolved with dimethyl sulfoxide and the optical density (OD) was measured using a Synerg $\mathrm{y}^{\mathrm{TM}}$ HT Multi-Detection Microplate Reader (Bio-Tek instruments Inc., Winooski, VT, USA) at $570 \mathrm{~nm}$. Cell viability (\%) was calculated as follows: $\left[\mathrm{OD}_{(\text {vandetanib) }}-\mathrm{OD}_{(\text {blank) }}\right] /$ $\left[\mathrm{OD}_{\text {(control) }}-\mathrm{OD}_{\text {(blank) }}\right] \times 100$.

Wound-healing assay. The migration ability of the ARPE19/EBV cells was analyzed using a wound-healing assay. The cells $\left(3 \times 10^{5} / 2 \mathrm{ml}\right)$ were seeded into a 6 -well plate. After incubation for $24 \mathrm{~h}$ at $37^{\circ} \mathrm{C}$, the confluent cell monolayers were manually scratched with a $200 \mu 1$ micropipette tip to create a cell-free area. The plates were washed with phosphate-buffered saline (PBS) to remove all cell debris and were then incubated with DMEM/F12 containing 10\% FBS in the presence or absence of vandetanib. Following $16 \mathrm{~h}$ treatment, repopulation of the wounded areas was observed under an inverted phase contrast microscope and the cells that migrated to the wounded area were imaged at x100 magnification. The number of cells that migrated into the scratched area was analyzed using ImageJ software (National Institutes of Health, Bethesda, MD, USA).

RNA isolation and RT-qPCR analysis. Total RNA was prepared using TRIzol reagent (Invitrogen; Thermo Fisher Scientific, Inc.) according to the manufacturer's protocol. 
Table I. Primer sequences used for reverse transcriptase-quantitative polymerase chain reaction.

Primers $\left(5^{\prime}-3^{\prime}\right)$

\begin{tabular}{llll}
\cline { 2 - 3 } Target & \multicolumn{1}{c}{ Forward } & \multicolumn{1}{c}{ Reverse } & Temp/cycles \\
\hline VEGFR2 & GTGACCAACATGGAGTCGTG & TGCTTCACAGAAGACCATGC & $62^{\circ} \mathrm{C} / 30$ \\
VEGF & AGGAGGGCAGAATCATCACG & CAAGGCCCACAGGGATTTCT & $66^{\circ} \mathrm{C} / 30$ \\
EGFR & AGGCACGAGTAACAAGCTCAC & ATGAGGACATAACCAGCCACC & $65^{\circ} \mathrm{C} / 25$ \\
EGF & CAGTTCCCACCACTTCAGGT & GCCAGCTGCACAAATACAGA & $58^{\circ} \mathrm{C} / 25$ \\
E-cadherin & GACGCGGACGATGATGTGAAC & TTGTACTGTTGTGGATTGAAG & $50^{\circ} \mathrm{C} / 30$ \\
N-cadherin & CACCCAACATGTTTACAATCAACAATGAGAC & CTGCAGCAACAGTAAGGACAA & $60^{\circ} \mathrm{C} / 30$ \\
& & ACATCCTATT & \\
Vimentin & GGAAGAGAACTTTGCCGTTGAA & GTGACGAGCCATTTCCTCCTT & $60^{\circ} \mathrm{C} / 30$ \\
Snail & CAGATGAGGACAGTGGGAAAGG & ACTCTTGGTGCTTGTGGAGCAG & $66^{\circ} \mathrm{C} / 30$ \\
$\alpha$-SMA & ATCACCATCGGAAATGAACG & CTGGAAGGTGGACAGAGAGG & $60^{\circ} \mathrm{C} / 28$ \\
$\beta$-actin & CAGGCACCAGGGCGT & ATGGCTGGGGTGTTGAAG & $60^{\circ} \mathrm{C} / 25$
\end{tabular}

VEGF, vascular endothelial growth factor; VEGFR2, VEGF receptor 2; EGF, epidermal growth factor; EGFR, EGF receptor; E, epithelial; N, neural; $\alpha$-SMA, $\alpha$-smooth muscle actin.

Briefly, the treated cells were harvested and washed twice with PBS following exposure to $1 \mathrm{ml}$ TRIzol and $0.2 \mathrm{ml}$ chloroform. Samples were vigorously vortexed for $15 \mathrm{sec}$ and incubated at room temperature for 2-3 min. Following centrifugation $\left(12,000 \times \mathrm{g}\right.$ for $15 \mathrm{~min}$ at $\left.4^{\circ} \mathrm{C}\right)$, the colorless upper aqueous phase was separated, mixed with $0.5 \mathrm{ml}$ of isopropyl alcohol, and centrifuged $(12,000 \mathrm{x} g$ for $10 \mathrm{~min}$ at $\left.4^{\circ} \mathrm{C}\right)$. Following removal of the supernatant, the RNA pellet was washed the twice with $1 \mathrm{ml} 75 \%$ ethanol and dried using a vacuum for $10 \mathrm{~min}$ at room temperature. For further removal of residual DNA, dissolved RNA samples in diethylpyrocarbonate-treated water were mixed with $2.5 \mu \mathrm{l}$ DNase I stock solution (no. 79254; Qiagen GmbH, Hilden, Germany) and incubated for $10 \mathrm{~min}$ at $25^{\circ} \mathrm{C}$. Purity of RNA samples $\left(\mathrm{A}_{260} / \mathrm{A}_{280}\right.$ ratio $\left.>1.6\right)$ was monitored with a Nanodrop 1000 spectrophotometer (Thermo Fisher Scientific, Inc.). Each RNA sample was transcribed into cDNA using oligo (dT) (no. N-7053; Bioneer Corporation, Daejeon, Korea) and AccuPower RT Premix (no. K-2043; 10 mM dNTPs; 2.5 mM, each dNTP; final concentration, $0.5 \mathrm{mM}$; Bioneer Corporation), oligo (dT)(5 $\mu \mathrm{M})$, RNase inhibitor (no. 2313A; $10 \mathrm{U} /$ $\mu \mathrm{l}$; Takara Bio, Inc., Otsu, Japan), and reverse transcriptase (100 U/ $\mu \mathrm{l}$; Bioneer Corporation). Following gentle agitation, the mixture was incubated at $42^{\circ} \mathrm{C}$ for $1 \mathrm{~h}$, and then heated at $94^{\circ} \mathrm{C}$ for $5 \mathrm{~min}$ to inactivate the reverse transcriptase. PCR was performed using Prime Taq Premix with Prime Taq DNA Polymerase, 1 unit/10 $\mu \mathrm{l} ; 2 \mathrm{X}$ reaction buffer; $4 \mathrm{mM} \mathrm{MgCl2}$; enzyme stabilizer; sediment; loading dye ( $\mathrm{pH} 9.0)$ and $0.5 \mathrm{mM}$ each of dATP, dCTP, dGTP, dTTP (no. G-3002; GeNet Bio, Daejeon, Korea) with the specified primers (Table I) and TaKaRa PCR Thermal Cycler Dice (no. TP600; Takara Bio, Inc.). The annealing temperature for specific target sequences and cycling conditions are provided in Table I. $\beta$-actin was used as a housekeeping gene. PCR products were analyzed by agarose gel (1\%) electrophoresis and visualized using ethidium bromide under ultraviolet light using the multiple Gel DOC system (Fujifilm, Tokyo, Japan). Each experiment was performed at least three times. Results are representative of three independent experiments.

Western blot analysis. The cells were washed with PBS and lysed in NP-40 cell lysis buffer (Thermo Fisher Scientific, Inc.) supplemented with a protease inhibitor cocktail (AEBSF, Aprotinin, bestatin hydrochloride, E-64, EDTA, and leupeptin hemisulfate salt; no. P8340; Sigma-Aldrich; Merck KGaA). To assess phosphorylation events, an additional set of phosphatase inhibitor Cocktail II (sodium orthovanadate, sodium molybdata, sodium tartrate, and imidazole; no. P5726; Sigma-Aldrich; Merck KGaA) was added to the NP-40 buffer. Equal quantities of protein (10 $\mu \mathrm{g} /$ lane) were separated using 8-12\% SDS-PAGE, then transferred to nitrocellulose membranes (Merck Millipore; Merck KGaA) at $340 \mathrm{~mA}$ for $2 \mathrm{~h}$. Following blocking with $5 \%$ nonfat skim milk for $1 \mathrm{~h}$ at room temperature, the membrane was probed with primary antibodies against Epstein-Barr virus nuclear antigen (EBNA) 2 (no. sc-17501; 1:100), EBNA3A (no. sc-23533; 1:100), latent membrane protein (LMP) 2A (no. sc-101314; 1:100), VEGFR2 (no. sc-6251; 1:500), ADAM10 (no. sc-25578; 1:500), ADAM12 (no. sc-25579; 1:500), ADAM17 (no. sc-25782; 1:500), E-cadherin (no. sc-7870; 1:500), $\beta$-actin (no. sc-47778; 1:1,000; all Santa Cruz Biotechnology, Inc., Santa Cruz, CA, USA); EGFR (no. 2232; 1:1,000), E-cadherin (no. 3195; 1:1,000), N-cadherin (no. 13116; 1:1000), Vimentin (no. 5741; 1:1,000), Snail (no. 3879; 1:1,000), phospho-Akt (Ser473; no. 9271; 1:1,000), Akt (no. 9272; 1:1,000), phospho-ERK1/2 (Thr202/Tyr204; no. 9101; 1:1,000), ERK1/2 (no. 9102; 1:1,000), phospho-JNK (Thr183/Tyr185; no. 4671; 1:1,000), JNK (no. 9258; 1:1,000), phospho-p38-MAPK (Thr180/Tyr182; no. 9211; 1:1,000), p38-MAPK (no. 9212; 1:1,000; all Cell Signaling Technology, Inc., Danvers, MA, USA); paired box protein (PAX) 2 (no. PAB24790; 1:500), LMP1 (no. MAB9772; 1:2,000; both Abnova, Taipei, Taiwan); EBNA1 (no. MA1-7271; 1:50; Thermo Fisher Scientific, Inc.); and $\alpha$-smooth muscle 
actin ( $\alpha$-SMA; no. bs-10196R; 1:1,000; Bioss, Inc., Woburn, MA, USA), followed by the following specific secondary antibodies: anti-mouse-horseradish peroxidase (HRP; no. K0211589; 1:3,000) or anti-rabbit-HRP (no. K0211708; 1:3,000; KOMABiotech, Seoul, Korea). Chemiluminescence was detected using a WesternBright electrochemiluminescence HRP substrate (no. K-12045-D50; Advansta, Inc., Menlo Park, CA, USA) and a Gel Doc system (Fujifilm). Each experiment was performed at least three times. Results are representative of three independent experiments. Quantifications of western blots were analyzed using ImageJ 1.38 software. Relative intensity of bands was calculated by Image $\mathrm{J}$ and expressed as relative values to $\beta$-actin.

Immunofluorescence assay using confocal microscopy. The cells $\left(3 \times 10^{5} / \mathrm{ml}\right)$ were seeded and treated with vandetanib and ADAM inhibitors. Following washing with PBS, the cells were fixed in $4 \%$ methanol-free formaldehyde solution (pH 7.4) at $4^{\circ} \mathrm{C}$ for $10 \mathrm{~min}$, permeabilized with $0.1 \%$ saponin in PBS for $10 \mathrm{~min}$ and blocked in blocking buffer at room temperature (5\% bovine serum albumin, $0.5 \%$ Tween-20 in PBS; no. A2058; Sigma-Aldrich; Merck KGaA) for $1 \mathrm{~h}$. The cells were then incubated with anti-E-cadherin antibody (no. sc-7870; 1:500; Santa Cruz Biotechnology, Inc.) for $24 \mathrm{~h}$ at room temperature, washed with PBS and incubated with the fluorescein isothiocyanate-labeled secondary antibody (no. F0382; 1:80; Sigma-Aldrich; Merck KGaA) for $1 \mathrm{~h}$ at room temperature. The cells were stained with a propidium iodide solution, mounted and visualized under a Zeiss LSM 510 Meta confocal laser-scanning microscope (Carl Zeiss AG, Oberkochen, Germany).

Statistical analysis. All data are presented as the mean \pm standard deviation from $\geq 3$ independent experiments. All statistics were calculated with the Student's $t$-test using SigmaPlot software (version 10.0; Systat Software, Inc., San Jose, CA, USA) and $\mathrm{P}<0.05$ was considered to represented a statistically significant difference.

\section{Results}

Cell characterization based on the expression of EMT-related molecules. The present study aimed to determine whether ARPE19/EBV cells exhibit fibroblast-like morphology and express mesenchymal cell markers. The ARPE19/EBV cells developed a characteristic small and spindle-like mesenchymal cell shape, and stably expressed the EBV-related viral proteins, including Epstein-Barr virus nuclear antigen EBNA1, EBNA2, EBNA3A, LMP1 and LMP2A (Fig. 1A). It was then investigated whether ARPE19/EBV cells exhibited EMT-related molecules, including mRNA and protein. Although EGF and VEGF mRNA were detected in the ARPE19 cells ARPE19/EBV cells, the levels of EGF, VEGF, EGFR and VEGFR2 mRNA were markedly increased in ARPE19/EBV cells (Fig. 1B). Increased expression of EGFR and VEGFR2 proteins were also detected in the ARPE19/ EBV cells compared with the ARPE19 cells (Fig. 1C). ARPE19/EBV cells exhibited mesenchymal-like cell features, including upregulated expression of vimentin, Snail and $\alpha$-SMA mRNA and protein. The cells also exhibited decreased E-cadherin and N-cadherin expression consistent with the loss of epithelial characteristics (Fig. 1B and C). In the ARPE19/EBV cells, the expression of ADAM10 and ADAM17 was upregulated compared with ARPE19 cells (Fig. 1C), however ADAM12 expression was not. Compared with the ARPE19 cells, increased expression of paired bow gene 2 (PAX2) protein, a regulatory transcriptional factor for ADAM10, was observed in the ARPE19/EBV cells (Fig. 1C). It was them determined whether exposure to vandetanib had an effect on cell viability of the ARPE19 and ARPE19/EBV cells. Although ARPE19/EBV cells were more sensitive to vandetanib, following $48 \mathrm{~h}$ vandetanib $(500 \mathrm{nM})$ treatment, both drug-treated ARPE19 and ARPE19/EBV cells had a survival rate $>80 \%$. However, the survival rate of vandetanib-treated ARPE19/EBV slightly decreased at $72 \mathrm{~h}$ (Fig. 1D). Based on these findings, the effect of vandetanib on ARPE19/EBV as a model of CNV to develop new treatment methods for retinal pathological conditions was evaluated.

Modulation of mesenchymal characteristics of ARPE19/EBV cells following treatment with vandetanib. The alteration of mesenchymal features in the ARPE19/EBV cells at 48 and $72 \mathrm{~h}$ following treatment with vandetanib was assessed. After $48 \mathrm{~h}$ treatment, the expression levels of VEGFR2 and EGFR in the ARPE19/EBV cells were attenuated compared with the untreated group following treatment with low $(50 \mathrm{nM})$ or high $(500 \mathrm{nM})$ doses of vandetanib (Fig. 2A). Epithelial cell markers of retina cells (E-cadherin and $\mathrm{N}$-cadherin) were also identified in the ARPE19/EBV cells treated with vandetanib (Fig. 2A). By contrast, the expression of proteins associated with mesenchymal characteristics (vimentin, Snail and $\alpha$-SMA) of ARPE19/EBV cells decreased in a dose-dependent manner following treatment with vandetanib (Fig. 2A). Similarly, treatment of ARPE19/EBV cells with vandetanib led to downregulation of ADAM10, ADAM17 and PAX2 expression in a dose-dependent manner (Fig. 2B). The mesenchymal characteristics of ARPE19/EBV cells were also considerably suppressed at $72 \mathrm{~h}$ after treatment with low or high doses of vandetanib (Fig. 2C and D). To determine the effect of vandetanib on migratory or invasive activity of the ARPE19/EBV cells, a wound healing assay was performed. Treatment with $500 \mathrm{nM}$ vandetanib significantly inhibited the migratory activity of the ARPE19/EBV cells $(\mathrm{P}<0.01$; Fig. 3A and B). Furthermore, vandetanib-treated ARPE19/EBV cells exhibited decreased wound healing capacity compared with the cells cultured in normal media or VEGF-supplemented conditioned media $(\mathrm{P}<0.001$; Fig. 3C and $\mathrm{D})$. These results suggest that vandetanib may recover the epithelial characteristics of EBV-infected ARPE19 cells and inhibit the migratory or invasive activity of RPE cells in a retina pathological condition.

Synergistic effect of vandetanib and ADAM inhibitors on mesenchymal features and migratory activity in ARPE19/ $E B V$ cells. Vandetanib affected the expression of ADAM family proteins in the ARPE19/EBV cells. To examine the effect of ADAM inhibitor on the expression of mesenchymal marker and invasion ability in the ARPE19/EBV cells, vandetanib was combined with ADAM inhibitors or a 
A

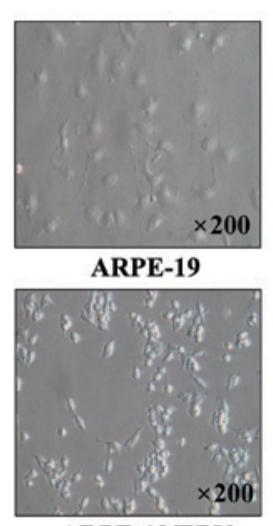

ARPE-19/EBV

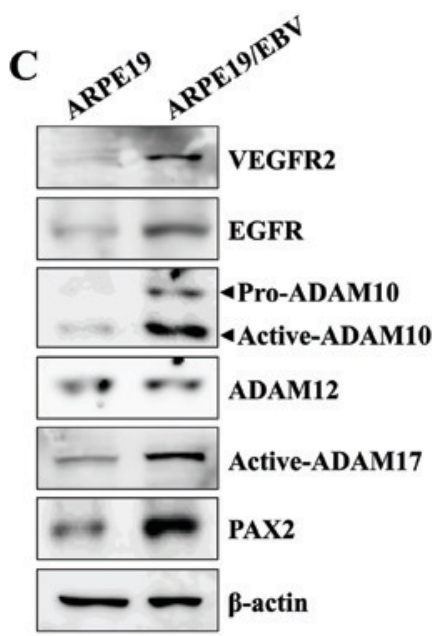

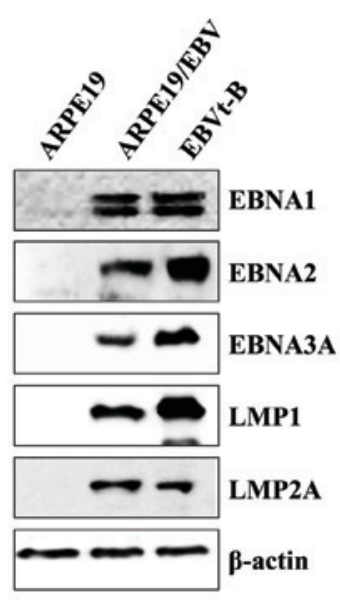

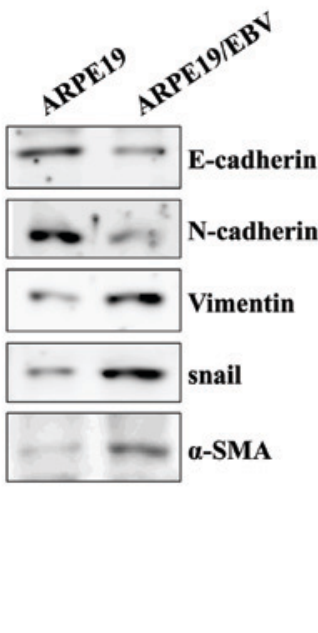

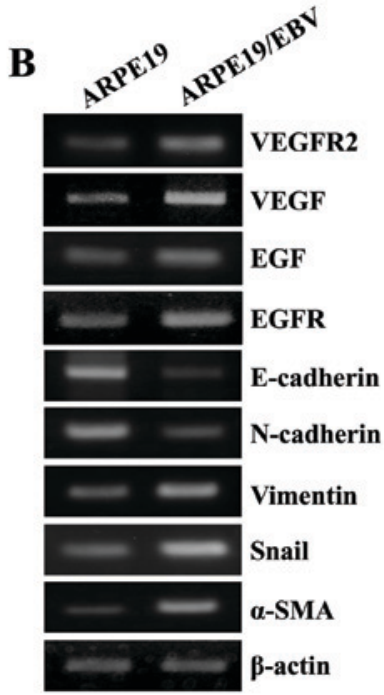

D

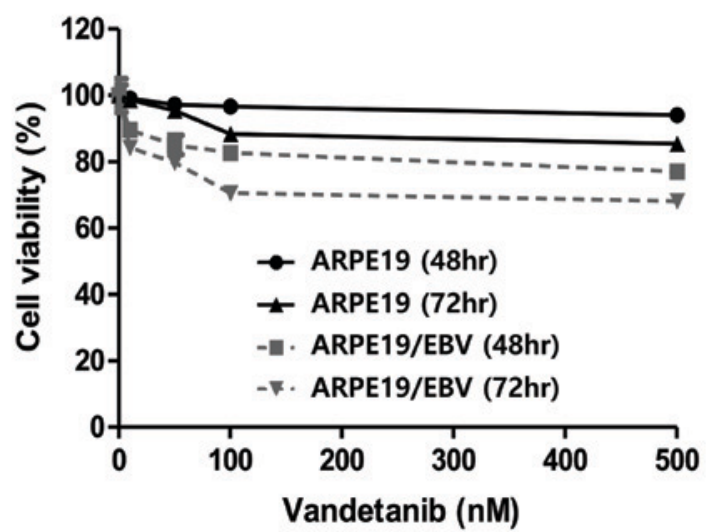

Figure 1. Mesenchymal morphology of ARPE19 cells elicited by EBV infection. (A) Mesenchymal cell-like transformation was observed under an inverted phase-contrast microscope and the level of EBV-related gene protein in EBV-infected ARPE19 cells was measured using western blotting. (B) Levels of VEGFR2, VEGF, EGFR, EGF, E-cadherin, N-cadherin, Vimentin, Snail, $\alpha$-SMA and $\beta$-actin mRNA in ARPE19 and ARPE19/EBV cells were determined by reverse transcription-polymerase chain reaction. (C) The levels of VEGFR2, EGFR, E-cadherin, N-cadherin, Vimentin, Snail, $\alpha$-SMA, pro-ADAM10, active-ADAM10, active-ADAM12, active-ADAM17, PAX2 and $\beta$-actin expression in ARPE19 and ARPE19/EBV cells were determined by western blot analysis. (D) ARPE19 and ARPE19/EBV cells were treated with various concentrations of vandetanib (0, 10, 50, $100 \mathrm{or} 500 \mathrm{nM})$ for 48 and $72 \mathrm{~h}$. Cell viability was analyzed by MTT assay. The results are representative of three independent experiments. ARPE19, adult retinal pigment epithelium-19 cells; EBV, Epstein-Barr virus; VEGF, vascular endothelial growth factor; VEGFR2, VEGF receptor 2; EGF, epidermal growth factor; EGFR, EGF receptor; $\alpha$-SMA, $\alpha$-smooth muscle actin; ADAM, disintegrin and metalloproteinase protein; PAX2, paired box gene 2; EBNA, Epstein-Barr virus nuclear antigen; LMP, latent membrane protein.

matrix metalloproteinase (MMP) inhibitor. In the ARPE19/ EBV cells, it was demonstrated that ADAM10 inhibitor (GI254023X) and ADAM17 inhibitor (Marimastat) significantly downregulated the expression of ADAM10 and ADAM17 respectively (Fig. 4A; $\mathrm{P}<0.01$ ). The MMP inhibitor (ONO4817) also slightly decreased the expression of ADAM 17 (Fig. 4A). The combination of low dose vandetanib and each inhibitor clearly reduced the expression of VEGFR2, EGFR and PAX2 (Fig. 4B). Furthermore, the expression of ADAM10 and ADAM17 in the ARPE19/EBV cells co-treated with vandetanib and each inhibitor was also downregulated, compared with cells treated with vandetanib alone (Fig. 4B). The expression of epithelial markers (E-cadherin and $\mathrm{N}$-cadherin) markedly increased following combination treatment with vandetanib and each inhibitor. Vimentin, Snail and $\alpha$-SMA expression were all decreased following co-treatment with vandetanib and each inhibitor (Fig. 4B). In addition, the combination treatment with vandetanib and each ADAM inhibitor markedly inhibited the migratory activity of the ARPE19/EBV cells compared with that of single drug treatment (Fig. 4C and D). To determine the recovery of epithelial markers (E-cadherin) in the ARPE19/EBV cells, an immunofluorescence analysis was performed and visualized using confocal microscopy. E-cadherin expression in the ARPE19/EBV cells was upregulated following treatment with vandetanib in a dose-dependent manner (Fig. 5A). Similarly, GI254023X, Marimastat and ONO4817 induced the expression of E-cadherin in the ARPE19/EBV cells (Fig. 5B). Furthermore, an evident increase in E-cadherin was observed in the ARPE19/EBV cells co-treated with vandetanib and each inhibitor compared with the cells treated with each inhibitor alone (Fig. 5C). These results suggest that a 

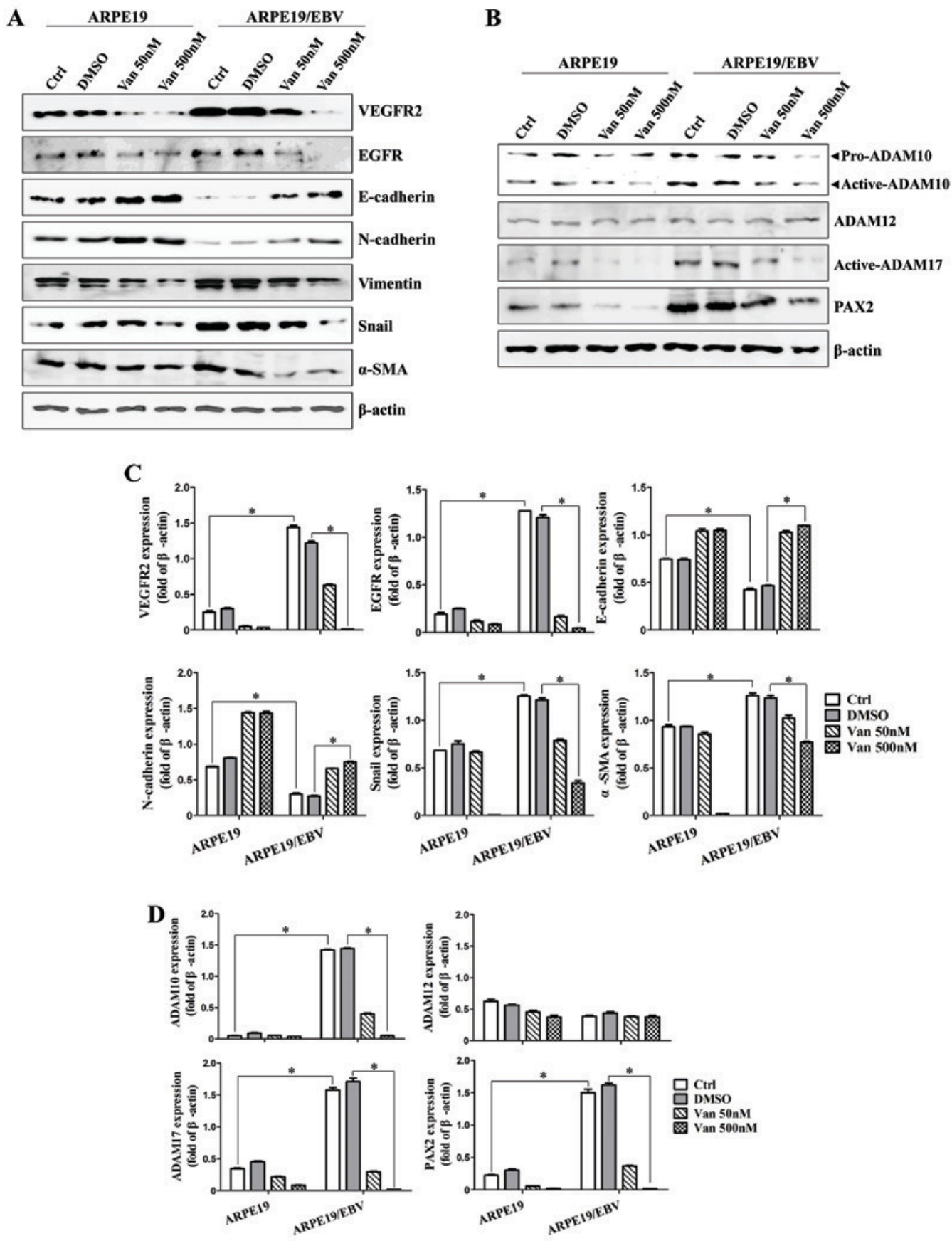

Figure 2. Van decreases the expression of VEGFR2, EGFR, ADAM family and EMT markers in ARPE19 and ARPE19/EBV cells. ARPE19 and ARPE19/EBV cells were treated with 0,50 and $500 \mathrm{nM}$ Van for (A and B) $48 \mathrm{~h}$ or (C and D) $72 \mathrm{~h}$. Whole cell lysates were analyzed by western blot analysis using antibodies against VEGFR2, EGFR, E-cadherin, N-cadherin, Vimentin, Snail, $\alpha$-SMA, pro-ADAM10, active-ADAM10, active-ADAM12, active-ADAM17, and PAX2 $\beta$-actin was used as an internal control. The results are representative of three independent experiments. $(\mathrm{C}$ and $\mathrm{D})$ The protein concentration in western blots was calculated using ImageJ software and expressed relative to $\beta$-actin. ${ }^{*} \mathrm{P}<0.01$. VEGFR2, vascular endothelial growth factor receptor 2; EGFR, epidermal growth factor receptor; ADAM, disintegrin and metalloproteinase protein; ARPE19, adult retinal pigment epithelium-19 cells; $\alpha$-SMA, $\alpha$-smooth muscle actin; PAX2, paired box gene 2; DMSO, dimethyl sulfoxide; Van, vandetanib; Ctrl, control; EBV, Epstein-Barr virus.

combination treatment with vandetanib and ADAM inhibitor may efficiently control the expression of mesenchymal features in RPE cells.

Effect of combining vandetanib and ADAM inhibitors on the MAPK signaling pathway to control EMT characteristics in ARPE19/EBV cells. Finally, the effect of co-treatment with vandetanib and an ADAM inhibitor on inhibiting the signaling pathway induced by VEGF in the ARPE19/EBV cells was evaluated. The expression levels of phosphorylated JNK and p38 MAPK were increased in the ARPE19/EBV cells compared with ARPE19 cells but expression of phosphorylated ERK was decreased in the ARPE19/EBV cells (Fig. 6A). Although the level of phosphorylated ERK was clearly increased following treatment with high doses of vandetanib, there was no effect on 
$\mathbf{A}$

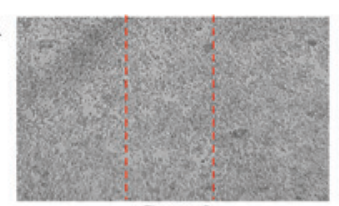

Control

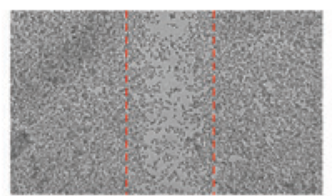

Van $50 \mathrm{nM}$

C

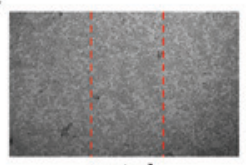

control

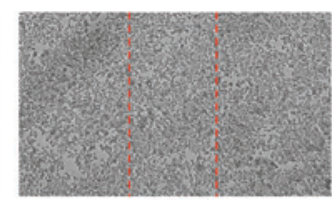

DMSO

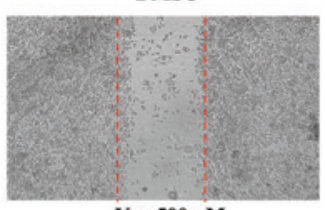

Van $500 \mathrm{nM}$
B

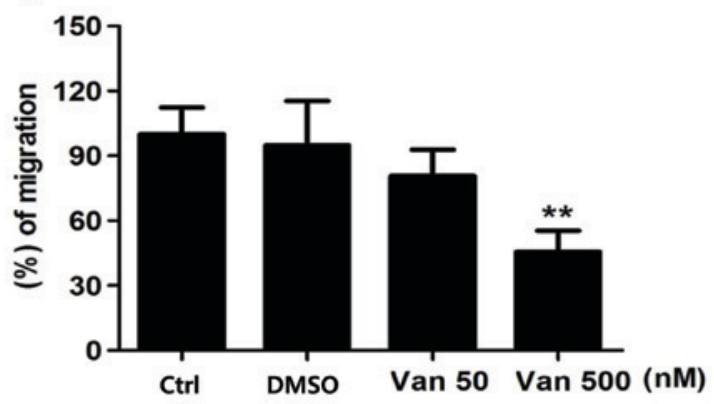

D

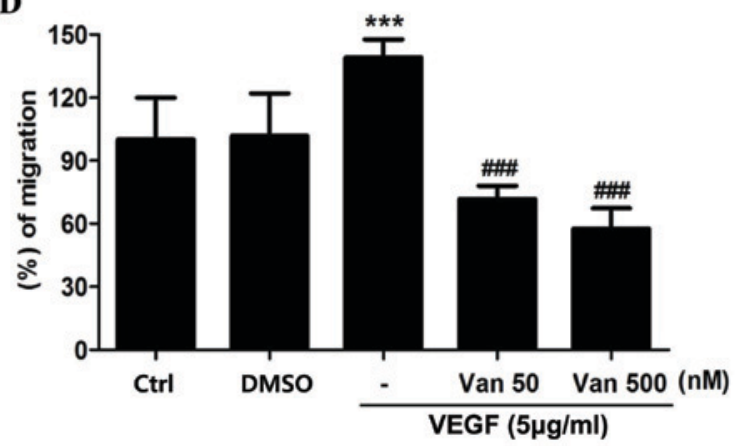

Figure 3. Van inhibits ARPE19/EBV cell migration. (A) ARPE19/EBV cells were treated with 0,50 and $500 \mathrm{nM}$ Van for $16 \mathrm{~h}$. The migration ability of the cells was analyzed using a wound-healing assay. The length of the cells that migrated into the scratched area was imaged and calculated as a percentage of migration. (B) Graph demonstrating the number of cells that migrated to the wounded areas. ${ }^{* *} \mathrm{P}<0.01 \mathrm{vs}$. control. (C) ARPE19/EBV cell were pretreated with $50 \mathrm{nM}$ Van for $3 \mathrm{~h}$ and then treated with recombinant VEGF $(5 \mu \mathrm{g} / \mathrm{ml})$ for $30 \mathrm{~min}$. Following washing with phosphate buffered saline, the cells were incubated for $16 \mathrm{~h}$. The length of the cells that migrated into the scratched area were imaged and calculated as a percentage of migration (D), ${ }^{* * *} \mathrm{P}<0.001$ vs. control; ${ }^{\# \# \# ~} \mathrm{P}<0.001$ vs. VEGF. The results are representative of three independent experiments. ARPE19, adult retinal pigment epithelium-19; VEGF, vascular endothelial growth factor; DMSO, dimethyl sulfoxide; Van, vandetanib; Ctrl, control.

the levels of phosphorylated JNK, p38 MAPK and Akt in ARPE19/EBV cells (Fig. 6A); however, co-treatment with a low dose of vandetanib and an ADAM or MMP inhibitor upregulated levels of phosphorylated ERK and attenuated the signaling pathway by blocking the phosphorylation of JNK, p38 MAPK and Akt (Fig. 6B). The upregulation of the VEGF-induced mesenchymal markers (vimentin, Snail and $\alpha$-SMA) and ADAM proteins was effectively blocked following co-treatment with low dose vandetanib and each inhibitor (Fig. 6C). In addition, the migratory activity of VEGF-treated ARPE19/EBV cells significantly decreased $(\mathrm{P}<0.01)$ following combination treatment with low dose of vandetanib and ADAM or MMP inhibitor (Fig. 6D and E). These results suggest that combination treatment with vandetanib and ADAM inhibitors regulate the VEGF-mediated migratory activity of ARPE19/EBV cells through modulation of the MAPK signaling pathway.

\section{Discussion}

VEGF expression is increased in RPE cells of the macula in patients with AMD, a condition associated with a high risk of CNV (2). CNV is a serious vision-limiting complication in which the integrity of the BM is compromised, allowing leaky tortuous vessels to sprout from the choriocapillaris into the subretinal pigment epithelium and the subretinal spaces $(7,8)$. In humans, it has been demonstrated that the vitreous level of VEGF is increased in patients with proliferative diabetic retinopathy (30). Therefore, intravitreal administration of neutralizing anti-VEGF monoclonal antibody is currently the primary treatment for AMD. Bevacizumab (Avastin ${ }^{\circledR}$ ) is a full-length antibody and ranibizumab (Lucentis ${ }^{\mathrm{TM}}$ ) is an antibody fragment. Both bind all isoforms of VEGF. Unfortunately, Bevacizumab increases the expression of $\alpha$-SMA and decreases the expression of zonula occludens-1 by stimulating the secretion of connective tissue growth factor (CTGF) in ARPE19 cells (31). CTGF is involved in the pathogenesis of PVR and retinal fibrosis, and serves an important role in EMT of RPE (32-34). In addition, AMD treated with anti-VEGF monoclonal antibodies generated undesirable additional hemorrhagic retinal lesions, which develop $\leq 3.5$ years following the initiation of therapy (35). Furthermore, VEGF depletion in adult mouse RPE cells rapidly leads to vision loss and dysfunction of cone photoreceptors in physiological and pathological states (36). Based on these results, novel targets or drugs to prevent the progression of AMD through additional regulation are required and were assessed in the present study. The results of the current study suggest that the combination of vandetanib and ADAM10 or ADAM17 inhibitors may synergistically control the AMD-related EMT of RPE cells by upregulating epithelial markers.

EBV infection induces the expression of a series of cell-invasiveness and angiogenic factors, including MMP9 (37), MMP1, MMP3 (38) and VEGF (39), regardless of the LMP-1 expression of EBV (40). It has been demonstrated that EBV-infected 


\section{$\mathbf{A}_{\text {题 }}$}
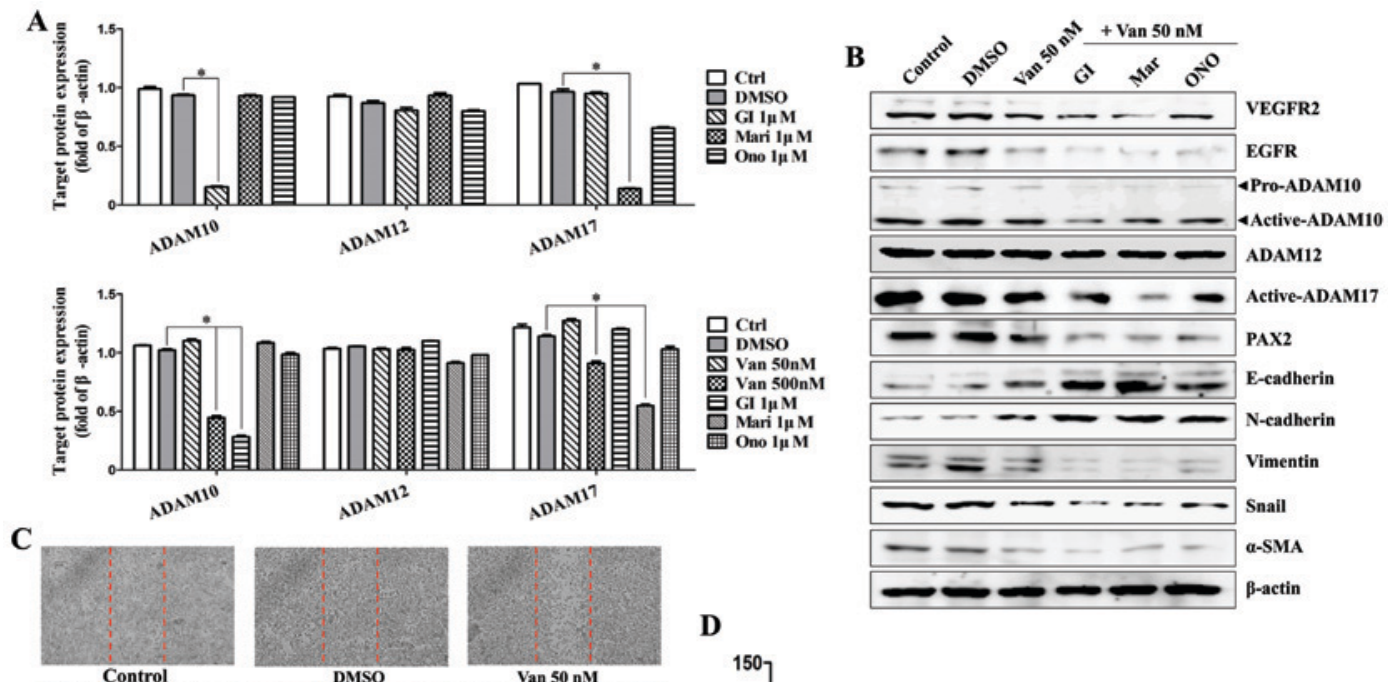

(D) 1 M12 $^{2}$

NDN $N 11$
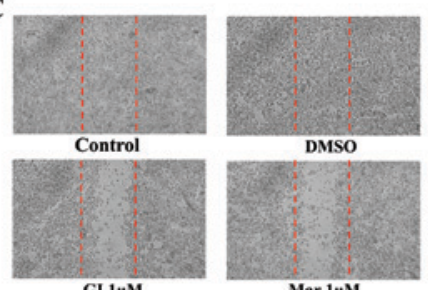

DMSO

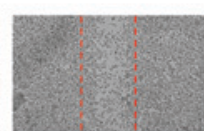

D

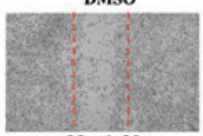

Van $50 \mathrm{nM}$

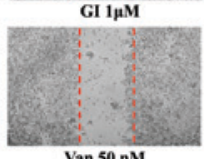

Mar $1 \mu \mathrm{M}$
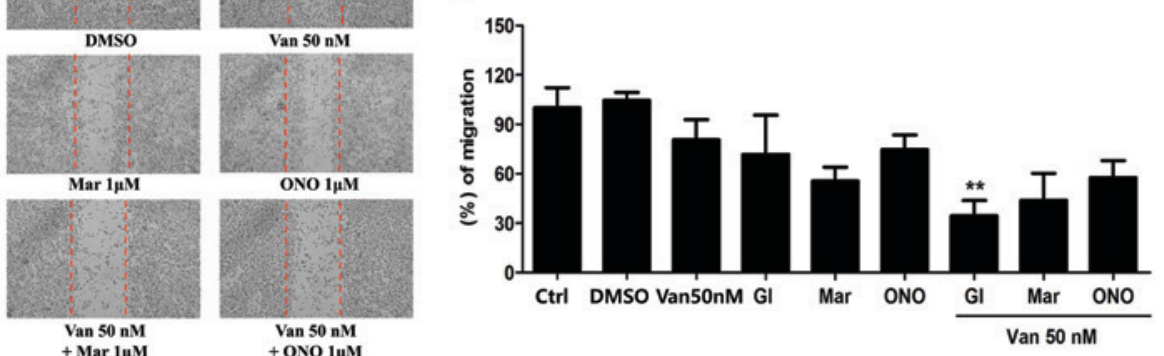

Figure 4. Inhibition of ADAMs enhances the inhibitory effects of vandetanib in ARPE19/EBV cells. (A) ARPE19/EBV cells were treated with various ADAM inhibitors to examine the effect against ADAM activity. ARPE19/EBV cells were treated with 0,50 or $500 \mathrm{nM}$ Van for $3 \mathrm{~h}$ to compare the blocking effect on ADAM activity. The cells were also treated with $1 \mu \mathrm{M}$ GI (ADAM10 inhibitor), $1 \mu \mathrm{M}$ Mari (ADAM17 inhibitor) or $1 \mu \mathrm{M}$ ONO (matrix metalloproteinase inhibitor) for $1 \mathrm{~h}$. Following washing with phosphate-buffered saline, the cells were incubated for $24 \mathrm{~h}$ in Dulbecco's modified Eagle's medium/F12 containing $10 \%$ fetal bovine serum. Whole cell lysates were analyzed by western blot analysis using antibodies against pro-ADAM10, active-ADAM10, active-ADAM12 and active-ADAM17. The protein concentration in western blots was calculated using Image J software and expressed relative to $\beta$-actin. ${ }^{*} \mathrm{P}<0.01$. (B) ARPE19/EBV cells were pre-treated with $50 \mathrm{nM}$ Van for $3 \mathrm{~h}$ and then exposed to $1 \mu \mathrm{M} \mathrm{GI}$, Mari or ONO for $1 \mathrm{~h}$. Following washing with phosphate-buffered saline, cells were maintained for $48 \mathrm{~h}$ Dulbecco's modified Eagle's medium/F12 containing 10\% fetal bovine serum. Whole cell lysates were analyzed by western blot analysis using antibodies against VEGFR2, EGFR, E-cadherin, N-cadherin, Vimentin, Snail, $\alpha$-SMA, pro-ADAM10, active-ADAM10, active-ADAM12, active-ADAM17, and PAX2. $\beta$-actin was used as an internal control. (C and D) Cell motility was measured by a wound-healing assay. Dotted lines indicate the initial wounded area. Wound closure was slower in cells treated with vandetanib and ADAM inhibitors compared with those treated with DMSO or a single drug. The migratory distance of the cells toward the scratched area was imaged and calculated as a percentage of migration. ${ }^{* *} \mathrm{P}<0.01 \mathrm{vs}$. Van $50 \mathrm{nM}$. The results are representative of three independent experiments. ADAM, disintegrin and metalloproteinase protein; ARPE19, adult retinal pigment epithelium-19; EBV, Epstein-Barr virus; GI, GI254023X; Mari, Marimastat; ONO, ONO4817; Van, vandetanib; DMSO, dimethyl sulfoxide; VEGFR2, vascular endothelial growth factor receptor 2; EGFR, epidermal growth factor receptor; $\alpha$-SMA, $\alpha$-smooth muscle actin; PAX2, paired box gene 2; Ctrl, control.
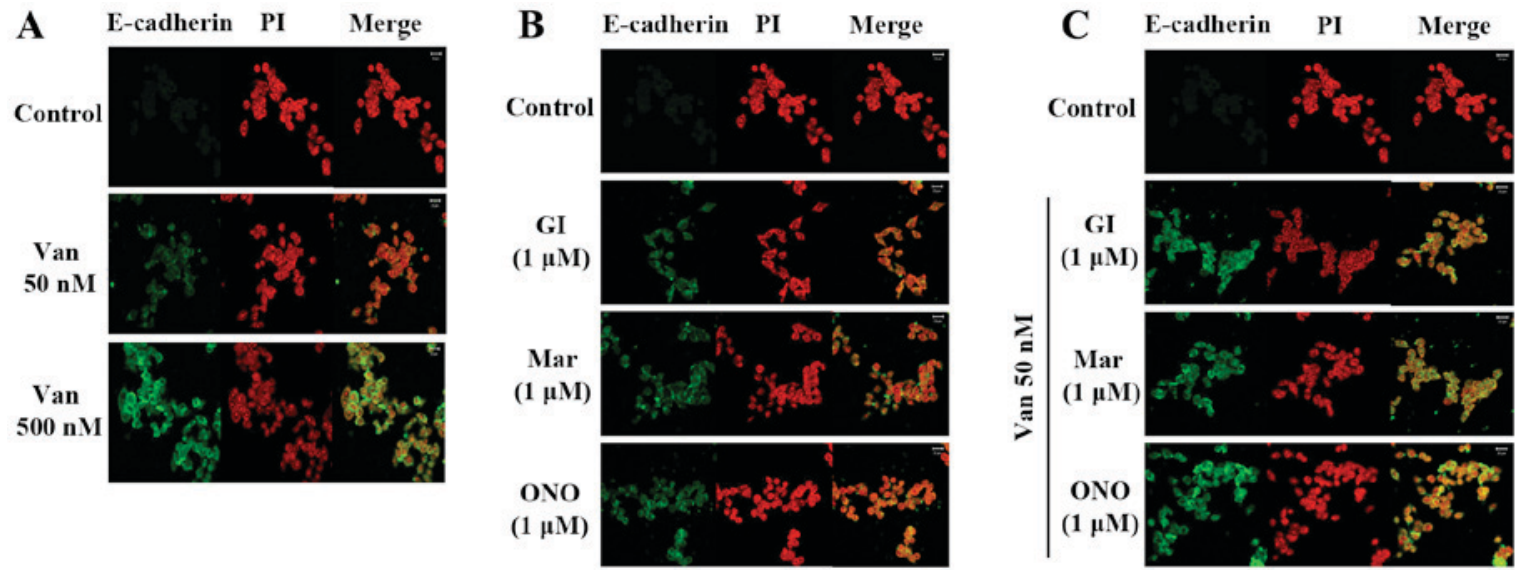

Figure 5. Van and ADAM inhibitors significantly increase E-cadherin in ARPE19/EBV cells. (A) ARPE19/EBV cells were treated with 0,50 or $500 \mathrm{nM}$ Van for $3 \mathrm{~h}$ and then maintained for $8 \mathrm{~h}$ in DMEM/F12 containing 10\% FBS (B) ARPE19/EBV cells were treated with ADAM inhibitors for $1 \mathrm{~h}$ and then maintained for $8 \mathrm{~h}$ in DMEM/F12 containing 10\% FBS. (C) ARPE19/EBV cells were pre-treated with $50 \mathrm{nM}$ Van for $3 \mathrm{~h}$ and then treated with ADAM inhibitors (GI, Mari, ONO) for $1 \mathrm{~h}$. Following washing with phosphate-buffered saline, the cells were maintained for $8 \mathrm{~h}$ in DMEM/F12 containing 10\% FBS. The nucleus was stained with PI. The cells were visualized under a confocal microscope (magnification, $\mathrm{x} 200$ ). Green fluorescence indicates E-cadherin and red fluorescence indicates the nucleus (scale bar, $20 \mu \mathrm{m}$ ). The results are representative of three independent experiments. ARPE19, adult retinal pigment epithelium-19; Van, vandetanib; ADAM, disintegrin and metalloproteinase protein; DMEM, Dulbecco's modified Eagle's medium; FBS, fetal bovine serum; GI, GI254023X; Mari, Marimastat; ONO, ONO4817; PI, propidium iodide. 
$\mathbf{A}$

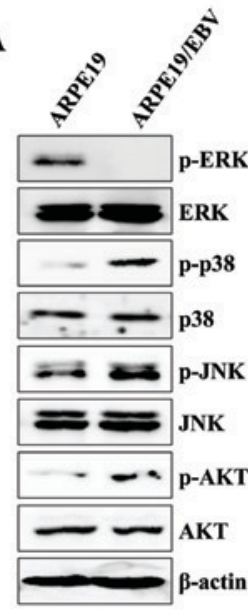

D

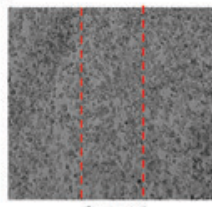

Control

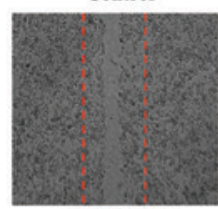

Van $50 \mathrm{nM}$

+ VEGF $5 \mu \mathrm{g} / \mathrm{ml}$

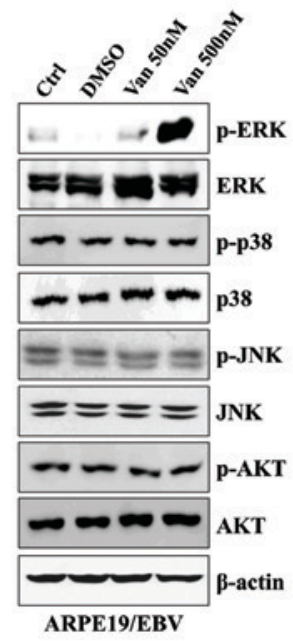

B

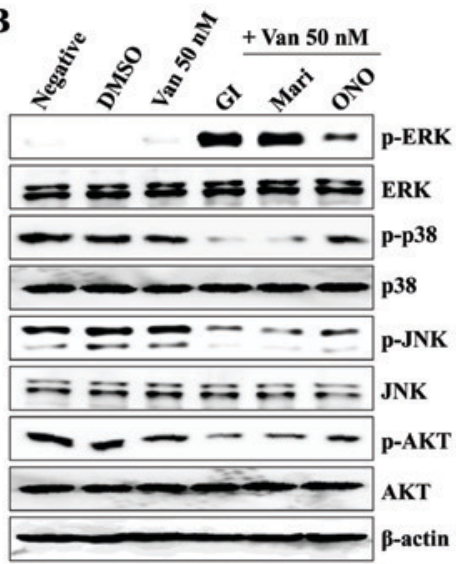

$\mathbf{E}$
C

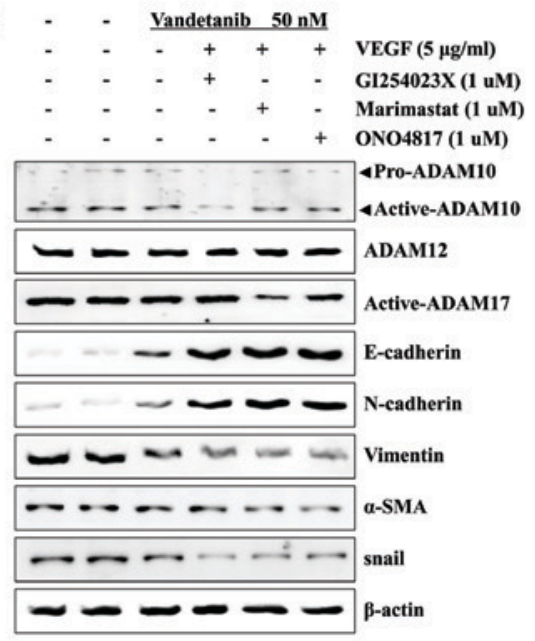

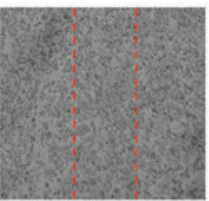

DMSO
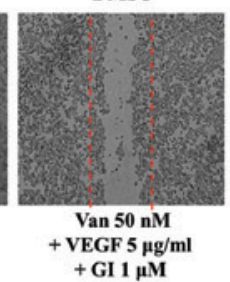

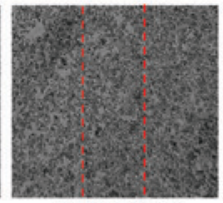

VEGF $5 \mu \mathrm{g} / \mathrm{ml}$

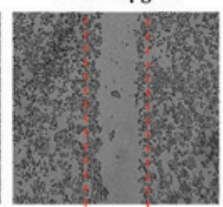

Van $50 \mathrm{nM}$

+ VEGF $5 \mu \mathrm{g} / \mathrm{m}$
+ Mar $1 \mu \mathrm{M}$

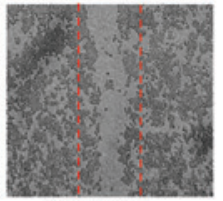

Van $50 \mathrm{nM}$

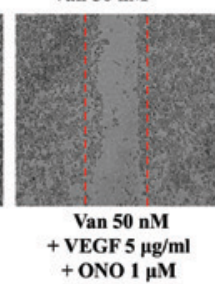

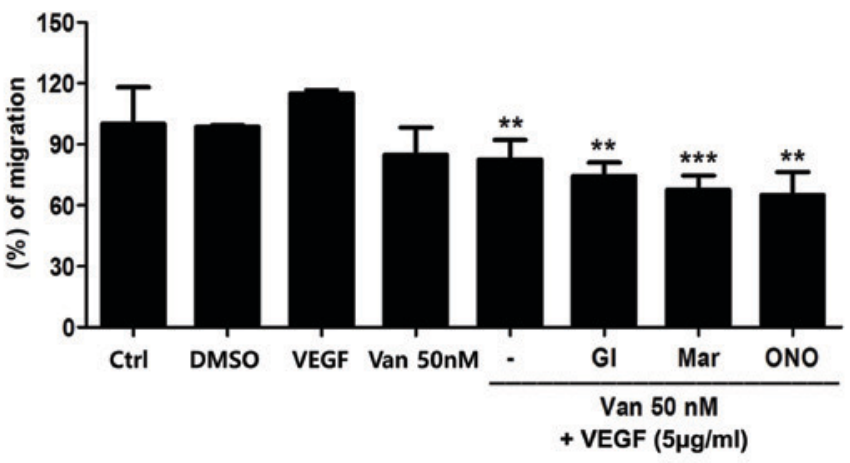

Figure 6. Combined treatment with Van and ADAM inhibitors attenuates the MAPK signaling pathway and reverses epithelial-mesenchymal transition markers in ARPE19/EBV cells. (A) Protein levels of p-ERK, ERK, p-p38, p38, p-JNK, JNK, p-AKT, and $\beta$-actin in ARPE19 and ARPE19/EBV cells. ARPE19/EBV cells treated with various concentrations of Van $(0,50,500 \mathrm{nM})$ for $3 \mathrm{~h}$ in order to analyze MAPK expression. (B) ARPE19/EBV cells were pre-treated with $50 \mathrm{nM}$ Van for $3 \mathrm{~h}$ and exposed to $1 \mu \mathrm{M}$ GI, Mari or ONO for $1 \mathrm{~h}$. Following washing with phosphate buffered saline, the cells were maintained for $24 \mathrm{~h}$ in DMEM/F12 containing 10\% FBS. Whole cell lysates were prepared and used in western blot analysis to determine the expression of p-ERK, ERK, p-p38, p38, p-JNK, JNK, p-AKT, AKT and $\beta$-actin, which served as an internal control. (C) ARPE19/EBV cells were pre-treated with Van (50 nM) for $3 \mathrm{~h}$ and then treated with recombinant VEGF $(5 \mu \mathrm{g} / \mathrm{ml})$ for $30 \mathrm{~min}$. Following VEGF treatment; the cells were treated with GI, Mari and ONO for $1 \mathrm{~h}$ and incubated for $8 \mathrm{~h}$ in DMEM/F12 containing 10\% FBS. Whole cell lysates were prepared and used for western blot analysis to determine the expression of pro-ADAM10, active-ADAM10, active-ADAM12, active-ADAM17, E-cadherin, N-cadherin, Vimentin, $\alpha$-SMA, snail and $\beta$-actin, which served as an internal control (D and E) The migration ability of the cells was analyzed using a wound healing assay. Dotted lines indicate the initial wounded area. The length of the cells that migrated into the scratched area was imaged (D) and calculated as a percentage of migration $(\mathrm{E}){ }^{* * *} \mathrm{P}<0.01,{ }^{* * * *} \mathrm{P}<0.001 \mathrm{vs}$. VEGF. The results are representative of three independent experiments. Van, Vandetanib; ADAM, disintegrin and metalloproteinase protein; MAPK, mitogen-activated protein kinase; ARPE19, adult retinal pigment epithelium-19; ERK, extracellular signal-regulated kinase; JNK, c-Jun N-terminal kinase; AKT, protein kinase B; DMEM, Dulbecco's modified Eagle's medium; FBS, fetal bovine serum; DMSO, dimethyl sulfoxide; GI, GI254023X; Mari, Marimastat; ONO, ONO4817; VEGF, vascular endothelial growth factor; $\alpha$-SMA, $\alpha$-smooth muscle actin; Ctrl, control; p-, phosphorylated.

HCECs exhibit increased migration and invasiveness due to the upregulation of MMP2 and MMP9 (27). Similarly, the present study indicated that EBV induced the loss of the epithelial marker E-cadherin and induced the upregulation of the mesenchymal markers (vimentin, Snail, and $\alpha$-SMA) in ARPE19 cells. Treatment with vandetanib also enhanced the expression of E-cadherin in epithelial cells. Furthermore, mesenchymal cells exhibit decreased vimentin expression following treatment with vandetanib in the presence of EGF and VEGF (41). Vandetanib is considered to be a potential postoperative adjuvant therapy to inhibit the proliferation, progression, migration and survival of cancer cells, as it serves a role in the regulation of the VEGFR and EGFR signaling pathways (42). However, this drug also induces various side-effects including diarrhea, hypertension and prolongation of the QT interval (43). It has been suggested that the PI3K/Akt pathway may be activated in a VEGFR1-dependent manner in certain cells $(44,45)$. Proteomic analysis has indicated that phosphorylated-EGFR and VEGFR2 are significantly inhibited by vandetanib in tumor tissues (46). In addition, vandetanib inhibits the phosphorylation of ERK1/2 (47). Thus, in the present study it was investigated whether the combination of vandetanib with an ADAM inhibitor influences the signaling pathway induced by VEGF. Phosphorylated ERK was increased following combination treatment with vandetanib and ADAM inhibitor or co-treatment with vandetanib and MMP inhibitor. Additionally, the ARPE19/EBV cells co-treated with vandetanib and an ADAM inhibitor more efficiently reduced the expression of VEGFR and suppressed the signal transduction by inhibiting the phosphorylation of JNK, p38-MAPK and Akt compared with cells treated with vandetanib alone. The results of the current study suggest that co-treatment with vandetanib and 
an ADAM inhibitor more effectively prevents the signal transduction underlying pathological migration of RPE cells, caused by VEGF/VEGFR2 in retinal diseases.

ADAM family proteins have emerged as major proteinases that mediate ectodomain shedding. The dysregulation of ectodomain shedding is associated with autoimmune and cardiovascular diseases, cancer, inflammation, infection and neurodegeneration (25). Inhibition of ADAM10 may inhibit Pax6 expression and N-cadherin ectodomain shedding in retinal cells, potentially affecting neurite outgrowth and differentiation of ganglion cells (48). Furthermore, the ectodomain shedding activity of ADAM17 demonstrates wide substrate specificity including cytokine receptors, TNF receptor, VEGFR2, adhesion molecules (such as L-selectin) and transforming growth factor- $\alpha(26,49)$. Inhibition of ADAM17 induces the expression of thrombospondin 1, a naturally occurring inhibitor of angiogenesis, whereas ADAM10 inhibition does not (50). Increased production of MMPs by TNF- $\alpha$ and ADAM17 activated by VEGF in the vascular endothelial cells serves a role in the regulation of retinal neovascularization (51). The endothelial-specific reduction of ADAM10 and inhibition of $\gamma$-secretase increases the collateral formation and endothelial-specific knockdown of ADAM17 reduced collateral formation (52); however, ADAM10 or ADAM17 inhibition exhibited a comparable influence on the invasion activity of the ARPE19/EBV cells in the current study. Furthermore, it was demonstrated that the combination of low dose vandetanib with an ADAM10 or ADAM17 inhibitor synergistically attenuated the migratory capacity of EBV-infected ARPE19 cells in an in vitro model of CNV or PVR. In conclusion, the results of the present study suggest that the inhibition of VEGF-mediated EMT signaling through co-treatment with vandetanib and an ADAM inhibitor provides a novel and promising therapeutic measure for neovascular AMD or other retina pathological conditions.

\section{Acknowledgements}

The present study was supported by a grant from the Korea Healthcare Technology R\&D Project of the Ministry of Health and Welfare Affairs, Republic of Korea (no. HI12C0005).

\section{References}

1. Kerbel RS: Tumor angiogenesis: Past, present and the near future Carcinogenesis 21: 505-515, 2000.

2. Kliffen M, Sharma HS, Mooy CM, Kerkvliet S and de Jong PT: Increased expression of angiogenic growth factors in age-related maculopathy. Br J Ophthalmol 81: 154-162, 1997.

3. Ida H, Tobe T, Nambu H, Matsumura M, Uyama M and Campochiaro PA: RPE cells modulate subretinal neovascularization, but do not cause regression in mice with sustained expression of VEGF. Invest Ophthalmol Vis Sci 44: 5430-5437, 2003.

4. Penn JS, Madan A, Caldwell RB, Bartoli M, Caldwell RW and Hartnett ME: Vascular endothelial growth factor in eye disease. Prog Retin Eye Res 27: 331-371, 2008.

5. Ferrara N, Houck K, Jakeman L and Leung DW: Molecular and biological properties of the vascular endothelial growth factor family of proteins. Endocr Rev 13: 18-32, 1992.

6. Tuccillo C, Romano M, Troiani T, Martinelli E, Morgillo F, De Vita F, Bianco R, Fontanini G, Bianco RA, Tortora G and Ciardiello F: Antitumor activity of ZD6474, a vascular endothelial growth factor- 2 and epidermal growth factor receptor small molecule tyrosine kinase inhibitor, in combination with SC-236, a cyclooxygenase-2 inhibitor. Clin Cancer Res 11: 1268-1276, 2005.
7. Ambati J and Fowler BJ: Mechanisms of age-related macular degeneration. Neuron 75: 26-39, 2012.

8. Swaroop A, Chew EY, Rickman CB and Abecasis GR: Unraveling a multifactorial late-onset disease: From genetic susceptibility to disease mechanisms for age-related macular degeneration. Annu Rev Genomics Human Genet 10: 19-43, 2009.

9. Campochiaro PA: Ocular neovascularization. J Mol Med (Berl) 91: 311-321, 2013.

10. Zarbin MA: Current concepts in the pathogenesis of age-related macular degeneration. Arch Ophthalmol 122: 598-614, 2004.

11. Aiello LP, Avery RL, Arrigg PG, Keyt BA, Jampel HD, Shah ST, Pasquale LR, Thieme H, Iwamoto MA, Park JE, et al: Vascular endothelial growth factor in ocular fluid of patients with diabetic retinopathy and other retinal disorders. New Engl J Med 331: 1480-1487, 1994.

12. Young RW: Pathophysiology of age-related macular degeneration. Sur Ophthalmol 31: 291-306, 1987.

13. Nagineni CN, Kommineni VK, William A, Detrick B and Hooks JJ: Regulation of VEGF expression in human retinal cells by cytokines: Implications for the role of inflammation in age-related macular degeneration. J Cell Physiol 227: 116-126, 2012.

14. Bao B, Ali S, Ahmad A, Azmi AS, Li Y, Banerjee S, Kong D, Sethi S, Aboukameel A, Padhye SB and Sarkar FH: Hypoxia-induced aggressiveness of pancreatic cancer cells is due to increased expression of VEGF, IL-6 and miR-21, which can be attenuated by CDF treatment. PLoS One 7: e50165, 2012.

15. Hirasawa M, Noda K, Noda S, Suzuki M, Ozawa Y, Shinoda K, Inoue M, Ogawa Y, Tsubota K and Ishida S: Transcriptional factors associated with pithelial-mesenchymal transition in choroidal neovascularization. Mol Vis 17: 1222-1230, 2011.

16. Noël A, Jost M,Lambert V, Lecomte J and Rakic JM: Anti-angiogenic therapy of exudative age-related macular degeneration: Current progress and emerging concepts. Trend Mol Med 13: 345-352, 2007.

17. Zhang SX and Ma JX: Ocular neovascularization: Implication of endogenous angiogenic inhibitors and potential therapy. Prog Ret Eye Res 26: 1-37, 2007.

18. Wedge SR, Ogilvie DJ, Dukes M, Kendrew J, Chester R, Jackson JA, Boffey SJ, Valentine PJ, Curwen JO, Musgrove HL, et al: ZD6474 inhibits vascular endothelial growth factor signaling, angiogenesis, and tumor growth following oral administration. Cancer Res 62: 4645-4655, 2002.

19. Heymach JV, Johnson BE, Prager D, Csada E, Roubec J, Pesek M, Spásová I, Belani CP, Bodrogi I, Gadgeel S, et al: Randomized, placebo-controlled phase II study of vandetanib plus docetaxel in previously treated non-small cell lung cancer. J Clin Oncol 25: 4270-4277, 2007.

20. Heymach JV, Paz-Ares L, De Braud F, Sebastian M, Stewart DJ, Eberhardt WE, Ranade AA, Cohen G, Trigo JM, Sandler AB, et al: Randomized phase II study of vandetanib alone or with paclitaxel and carboplatin as first-line treatment for advanced non-small-cell lung cancer. J Clin Oncol 26: 5407-5415, 2008.

21. Sarkar S, Mazumdar A, Dash R, Sarkar D, Fisher PB and Mandal M: ZD6474, a dual tyrosine kinase inhibitor of EGFR and VEGFR-2, inhibits MAPK/ERK and AKT/PI3-K and induces apoptosis in breast cancer cells. Cancer Biol Ther 9: 592-603, 2010

22. Klettner A and Roider J: Constitutive and oxidative-stress-induced expression of VEGF in the RPE are differently regulated by different Mitogen-activated protein kinases. Graefes Arch Clin Exp Ophthalmol 247: 1487-1492, 2009.

23. Yan X, Lin J, Rolfs A and Luo J: Differential expression of the ADAMs in developing chicken retina. Dev Growth Differ 53: 726-739, 2011.

24. Sel S, Kalinski T, Enssen I, Kaiser M, Nass N, Trau S, Wollensak G, Bräuer L, Jäger K and Paulsen F: Expression analysis of ADAM17 during mouse eye development. Ann Anat 194: 334-338, 2012.

25. Saftig P and Reiss K: The 'A Disintegrin and Metalloproteases' ADAM10 and ADAM17: Novel drug targets with therapeutic potential? Eur J Cell Biol 90: 527-535, 2011.

26. Swendeman S, Mendelson K, Weskamp G, Horiuchi K, Deutsch U, Scherle P, Hooper A, Rafii S and Blobel CP: VEGF-A stimulates ADAM17-dependent shedding of VEGFR 2 and crosstalk between VEGFR2 and ERK signaling. Circ Res 103: 916-918, 2008.

27. Park GB, Kim D, Kim YS, Kim S, Lee HK, Yang JW and Hur DY: The Epstein-Barr virus causes epithelial-mesenchymal transition in human corneal epithelial cells via Syk/src and Akt/Erk signaling pathways. Invest Ophthalmol Vis Sci 55: 1770-1779, 2014. 
28. Li H, Li M, Xu D, Zhao C, Liu G and Wang F: Overexpression of Snail in retinal pigment epithelial triggered epithelial-mesenchymal transition. Biochem Biophys Res Commun 446: 347-351, 2014.

29. Saika S, Kono-Saika S, Tanaka T, Yamanaka O, Ohnishi Y, Sato M, Muragaki Y, Ooshima A, Yoo J, Flanders KC and Roberts AB: Smad3 is required for dedifferentiation of retinal pigment epithelium following retinal detachment in mice. Lab Invest 84: 1245-1258, 2004.

30. Adamis AP, Miller JW, Bernal MT, D'Amico DJ, Folkman J, Yeo TK and Yeo KT: Increased vascular endothelial growth factor levels in the vitreous of eyes with proliferative diabetic retinopathy. Am J Ophthalmol 118: 445-450, 1994.

31. Chen CL, Liang CM, Chen YH, Tai MC, Lu DW and Chen JT: Bevacizumab modulates epithelial-to-mesenchymal transition in the retinal pigment epithelial cells via connective tissue growth factor up-regulation. Acta Ophthalmol 90: e389-e398, 2012.

32. Kon CH, Occleston NL, Aylward GW and Khaw PT: Expression of vitreous cytokines in proliferative vitreoretinopathy: A prospective study. Invest Ophthalmol Vis Sci 40: 705-712, 1999.

33. Leask A and Abraham DJ: The role of connective tissue growth factor, a multifunctional matricellular protein, in fibroblast biology. Biochem Cell Biol 81: 355-363, 2003.

34. Parapuram SK, Chang B, Li L, Hartung RA, Chalam KV, Nair-Menon JU, Hunt DM and Hunt RC: Differential effects of TGFbeta and vitreous on the transformation of retinal pigment epithelial cells. Invest Ophthalmol Vis Sci 50: 5965-5974, 2009.

35. Tanaka E, Chaikitmongkol V, Bressler SB and Bressler NM: Vision-threatening lesions developing with longer-term follow-up after treatment of neovascular age-related macular degeneration. Ophthalmology 122: 153-161, 2015.

36. Kurihara T, Westenskow PD, Bravo S, Aguilar E and Friedlander M: Targeted deletion of Vegfa in adult mice induces vision loss. J Clin Invest 122: 4213-4217, 2012.

37. Yoshizaki T, Sato H, Furukawa M and Pagano JS: The expression of matrix metalloproteinase 9 is enhanced by Epstein-Barr virus latent membrane protein 1. Proc Natl Acad Sci USA 95: 3621-3626, 1998.

38. Kondo S, Wakisaka N, Schell MJ, Horikawa T, Sheen TS, Sato H, Furukawa M, Pagano JS and Yoshizaki T: Epstein-Barr virus latent membrane protein 1 induces the matrix metalloproteinase-1 promoter via an Ets binding site formed by a single nucleotide polymorphism: Enhanced susceptibility to nasopharyngeal carcinoma. Int J Cancer 115: 368-376, 2005.

39. Murono S, Inoue H, Tanabe T, Joab I, Yoshizaki T, Furukawa M and Pagano JS: Induction of cyclooxygenase-2 by Epstein-Barr virus latent membrane protein 1 is involved in vascular endothelial growth factor production in nasopharyngeal carcinoma cells. Proc Natl Acad Sci USA 98: 6905-6910, 2001.

40. Lin JC, Liao SK, Lee EH, Hung MS, Sayion Y, Chen HC, Kang CC, Huang LS and Cherng JM: Molecular events associated with epithelial to mesenchymal transition of nasopharyngeal carcinoma cells in the absence of Epstein-Barr virus genome. J Biomed Sci 16: 105, 2009.
41. Li Y, Yang X, Su LJ and Flaig TW: VEGFR and EGFR inhibition increases epithelial cellular characteristics and chemotherapy sensitivity in mesenchymal bladder cancer cells. Oncol Rep 24: 1019-1928, 2010.

42. Yoshikawa D, Ojima H, Kokubu A, Ochiya T, Kasai S, Hirohashi S and Shibata T: Vandetanib (ZD6474), an inhibitor of VEGFR and EGFR signalling, as a novel molecular-targeted therapy against cholangiocarcinoma. Br J Cancer 100: 1257-1266, 2009.

43. Chau NG and Haddad RI: Vandetanib for the treatment of medullary thyroid cancer. Clin Cancer Res 19: 524-529, 2013.

44. Matsuzaki H, Tamatani M, Yamaguchi A, Namikawa K, Kiyama H, Vitek MP, Mitsuda N and Tohyama M: Vascular endothelial growth factor rescues hippocampal neurons from glutamate-induced toxicity: Signal transduction cascades. FASEB J 15: 1218-1220, 2001.

45. Roberts DM, Kearney JB, Johnson JH, Rosenberg MP, Kumar R and Bautch VL: The vascular endothelial growth factor (VEGF) receptor Flt-1 (VEGFR-1) modulates Flk-1 (VEGFR-2) signaling during blood vessel formation. Am J Pathol 164: 1531-1535, 2004.

46. Inoue $\mathrm{K}$, Torimura $\mathrm{T}$, Nakamura $\mathrm{T}$, Iwamoto $\mathrm{H}$, Masuda $\mathrm{H}$, Abe M, Hashimoto O, Koga H, Ueno T, Yano H and Sata M: Vandetanib, an inhibitor of VEGF receptor-2 and EGF receptor, suppresses tumor development and improves prognosis of liver cancer in mice. Clin Cancer Res 18: 3924-3933, 2012.

47. Giannelli G, Azzariti A, Sgarra C, Porcelli L, Antonaci S and Paradiso A: ZD6474 inhibits proliferation and invasion of human hepatocellular carcinoma cells. Biochem Pharmacol 71: 479-485, 2006

48. Paudel S, Kim YH, Huh MI, Kim SJ, Chang Y, Park YJ, Lee KW and Jung JC: ADAM10 mediates N-cadherin ectodomain shedding during retinal ganglion cell differentiation in primary cultured retinal cells from the developing chick retina. J Cell Biochem 114: 942-954, 2013.

49. Peschon JJ, Slack JL, Reddy P, Stocking KL, Sunnarborg SW Lee DC, Russell WE, Castner BJ, Johnson RS, Fitzner JN, et al: An essential role for ectodomain shedding in mammalian development. Science 282: 1281-1284, 1998.

50. Caolo V, Swennen G, Chalaris A, Wagenaar A, Verbruggen S, Rose-John S, Molin DG, Vooijs M and Post MJ: ADAM10 and ADAM17 have opposite roles during sprouting angiogenesis. Angiogenesis 18: 13-22, 2015.

51. Majka S, McGuire PG and Das A: Regulation of matrix metalloproteinase expression by tumor necrosis factor in a murine model of retinal neovascularization. Invest Ophthalmol Vis Sci 43: 260-266, 2002.

52. Lucitti JL, Mackey JK, Morrison JC, Haigh JJ, Adams RH and Faber JE: Formation of the collateral circulation is regulated by vascular endothelial growth factor-A and a disintegrin and metalloprotease family members 10 and 17 . Circ Res 111: 1539-1550, 2012. 